\title{
部分撥水領域を有するフラットスラスト軸受の水潤滑特性基礎
}

竹内 彰敏*1

\section{A study on fundamental water lubrication characteristics of flat thrust bearing with partial water-repellent regions}

\author{
Akitoshi TAKEUCHI ${ }^{*}$ \\ ${ }^{* 1}$ School of System Engineering, Kochi University of Technology \\ 185 Miyanokuchi, Tosayamada-cho, Kami-shi, Kochi 782-8502, Japan
}

Received: 14 June 2020; Revised: 3 October 2020; Accepted: 9 December 2020

\begin{abstract}
The water lubrication characteristic of partial water-repellent (slip) type flat thrust bearings was examined. In this bearing, water-repellent (slip) regions and hydrophilic (non-slip) regions were alternately arranged in the slip direction, and the pressure to support the load was generated by discontinuity of shear flow rate in both regions. The measured pressure in slip direction increases in the water-repellent region and then decreases in the hydrophilic region, and it increases in proportion to the load. The fundamental lubrication characteristics of this bearing were considered based on the infinite-width bearing approximation theory that can explain the experimental tendency. On bearing surfaces with large slip length, the shear flow rate increases and a high pressure is generated, resulting in a large load capacity. However, the influence of pressure flow that suppresses the slip of shear flow increases, and the degree of increase in load capacity with increase of the slip length becomes low, under the condition of large slip length and thin film. On the other hand, the film thickness increases and the velocity gradient on the slip surface decreases under the same load for large slip length bearing, so the frictional force tends to decrease. However, the difference in friction force due to the difference in slip length is not remarkable. Since the degree of increase in frictional force is lower than that in load capacity in case of decreasing film thickness, the friction coefficient decreases with decreasing film thickness. Especially, a sudden decrease of friction coefficient is shown in the thin film region. Since the effect of slip on frictional force is also small, the difference in friction coefficient due to the difference in slip length decreases as the film thickness becomes thinner. The slip effect in this bearing acts to improve the bearing characteristics.
\end{abstract}

Keywords : Slip flow, Water-repellent, Thrust bearing, Pressure distribution, Water lubrication

\section{1. 緒 言}

従来のすべり軸受では，流れ方向に幾何学的な先すぼまり領域を設けることにより，すべり方向へのせん断流 量の不連続性を生み出し，それを補う圧力流れ（したがって圧力）を誘起させて流量の連続性を確保し，負荷さ れる荷重を支持している.しかし，上記のせん断流量の不連続性が発生し，潤滑膜が保持される軸受面であれば， 幾何学的な先すぼまり領域を持たない滑らかで平坦な平行すべり面であっても, 圧力を発生させることができる. ストレッチ効果や熱くさび効果は周知の例であるが，壁面スリップの有無によるせん断流量差の付与もまた，圧 力発生のメカニズムの一つになると考えられる（竹内，2011）.

そのような壁面スリップについては古くから多くの研究が行われており，例えば希薄流体のスリップ流れにつ いては，速度勾配やすべり係数がスリップ速度に与える影響や抗力係数等の減少が（Millikan, 1923a）（Millikan， 1923b）（Hamid and Morteza, 2012），液体のスリップについては，スリップ長さ（スリップのし易さを表わす指標） のせん断速度への依存性が明らかにされている（Zhu and Granick, 2001）（川原他, 2010）。そして，例えば長山の

No.20-00226 [DOI:10.1299/transjsme.20-00226], J-STAGE Advance Publication date : 18 December, 2020

*1 正員, 高知工科大学システム工学群（†782-8502 高知県香美市土佐山田町宮ノ口 185）

E-mail of corresponding author: takeuchi.akitoshi@kochi-tech.ac.jp 
解説によれば, 実験的研究において求められた固液界面での水のスリップ長さは, およそ数 $\mathrm{nm}$ から数十 $\mu \mathrm{m}$ と されている（長山，2011）.

この他, 分子動力学でのスリップの確認も行われており, 上述したスリップ長さのせん断速度依存性や, 静的 接触角が大きく表面エネルギーが小さな高撥水面であるほどスリップ長さが長くなること等. 壁面でのスリップ に関する基礎的で重要な事項が明らかにされている（Voronov et al., 2006）（鳥居，小原，2005). 類似の結果は, 間隔約 $5.5 \mathrm{~nm}$ のナノチャンネルでの流動現象の解析でも確認されている他（長山，鶴田，2007）, 溶融樹脂の壁 面スリップに対する固体界面の影響の可視化実験や流動解析においても，静的接触角（ぬれ角）が大きく付着仕 事が小さい面ほどスリップ速度が大きくなる結果が得られている（加納他，1996）（加納他，1997).

そのような壁面でのスリップは，超撥水面についても実験的に確認されている．例えば渡辺らは，水滴の静的 接触角 $\theta$ が大きな超撥水壁面でのスリップ速度のせん断応力依存性や, スリップによる管摩擦係数の減少（渡辺 他，1996）（渡辺他，1997）, 超撥水性回転円板と固定壁面間での抵抗の減少を確認している（渡辺，小方，1997）.

ところで, 壁面スリップの有効性は, ステップ軸受や傾斜平面すべり軸受を含む多くの潤滑面について主に理 論的に検討されており（Ma et al., 2007), 例えば, リングオンプレート試験機での摩擦低減（Choo et al., 2007a）

(Choo et al., 2007b)， スリップ領域の適正配置によるメカニカルシールの支持荷重の増大と摩擦の低減や漏れ量 の減少等の性能向上，ジャーナル軸受の特性改善（Salant, 2003）（Fortier and Salant, 2005）がある.さらには，単 一テクスチャ軸受の流体潤滑性能に及ぼすスリップ位置の影響（Tauviqirrahman et al., 2016），軸受面での部分的な テクスチャやスリップパターンによる摩擦の低減と支持荷重の増大（Rao et al., 2012）（Rao, 2009），スリップモデ ルと粗さモデルを組み合わせた多孔質レイリーステップ軸受の磁性流体潤滑特性（Snehal and Gunamani，2013）, マイクロポーラ流体で潤滑されたスライダベアリングの潤滑特性に及ぼすスリップの影響（Pentyala and Santosh, 2018）等，多くの解析結果が明らかにされてきた.

このような撥水面でのスリップとそれによる摩擦の低減効果は，鏡のように平滑で平坦な面を持つ平行しゅう 動面での軸受機能の発現と，低摩擦での運転を可能にするものと期待できる．これに関して筆者らはすでに，扇 状の撥水領域と同面積の親水領域を交互に配置したフラットなスラスト軸受（ガラス円板）を用いて，水潤滑下 での起動特性や摩擦特性を調べ，軸受特性数の広い範囲にわたって低く安定した摩擦特性（例えば， $W=100 \mathrm{~N}$ で の摩擦係数が $\mu=0.0015 ）$ が得られ，しゅう動面の損傷も皆無であること等を明らかにしている（Takeuchi，2010）

(竹内, 北邑, 2011).

また，前述したスリップのし易さの指標となる撥水面での静的接触角 $\theta$ や，扇状の撥水部面積が全軸受面積に 占める割合（撥水部面積割合） $\beta$ を変えた試験片を用いて, 摩擦特性と超音波法での潤滑膜厚の測定を行い, $\theta$ が 大きく親水部とのせん断流量差が多くなる軸受ほど膜厚は厚くなり摩擦が低く安定すること, 撥水部と親水部の 面積が等しい $\beta=0.5$ 付近において, 厚膜で良好な軸受特性が得られること等, 本軸受の主要な特性の幾つかも確 認されている（竹内, 2013)。これらの基本特性は，一般的なステップ軸受と類似した傾向を示すものであり，本 スラスト軸受が幾何学的な先すぼまり領域を持つ従来の軸受と類似のメカニズムにより作動する可能性を示して いる. 本報では，上述した $\beta=0.5$ の軸受を用いて，圧力の発生の有無やその傾向を把握するとともに，本軸受の 水潤滑特性について, 最も単純な無限幅軸受近似理論を基に考察した結果について述べる.

\section{2. 実験装置と試験軸受ならびに圧力測定結果}

実験では，図 1 に示すスラスト軸受試験装置を用いた，図に示すように，部分撥水処理を施した，滑らかで平 坦な固定試験片（部分撥水処理を施さない状態では，基本的に，圧力の発生が望めない）の潤滑面は，回転水槽 の中心に固定された全面親水処理（HT）を施した回転試験片（滑らかで平坦）と端面接触をする. 荷重の負荷は ばね力により行い, 負荷用のシャフトの軸心は, 回転水槽の回転中心と一致するよう調整されている. 負荷用シ ヤフトと同軸にある固定試験片は，先端にピポット支持部を有する同シャフトで回転試験片に押しつけられ，そ こでの摩擦力はロードセルにより計測される摩擦トルクから求められる. 本実験での摩擦力 $F$ は, 摩擦面全体の 微小摩擦トルクの総和と等しいトルクになる, 等価半径 $R_{E}$ （下記の試験片では $R_{E}=13 \mathrm{~mm}$ ）に作用する力 $F$ で定 義した. また, その半径での回転試験片の周速をすべり速度 $U\left(U=2 \pi R_{E} N / 1000\right)$ としている. ただし $N$ は毎秒回 転数であり，従前の実験と同じく $N=1.83 \mathrm{rps}$, したがって $U=0.15 \mathrm{~m} / \mathrm{s}$ とした（竹内，北邑，2011）。一方，荷重 $W$ 
は 5 30N（平均圧力 $p_{m}$ は 5 30kPa）の範囲で負荷した.なお，潤滑剤にはイオン交換により精製された精製水 を用い，実験にあたっては，水槽や試験片を洗浄後に新たな精製水を注入して潤滑剤とした．実験中の精製水の 温度は，実験を通して $24 \pm 1{ }^{\circ} \mathrm{C}$ であった。

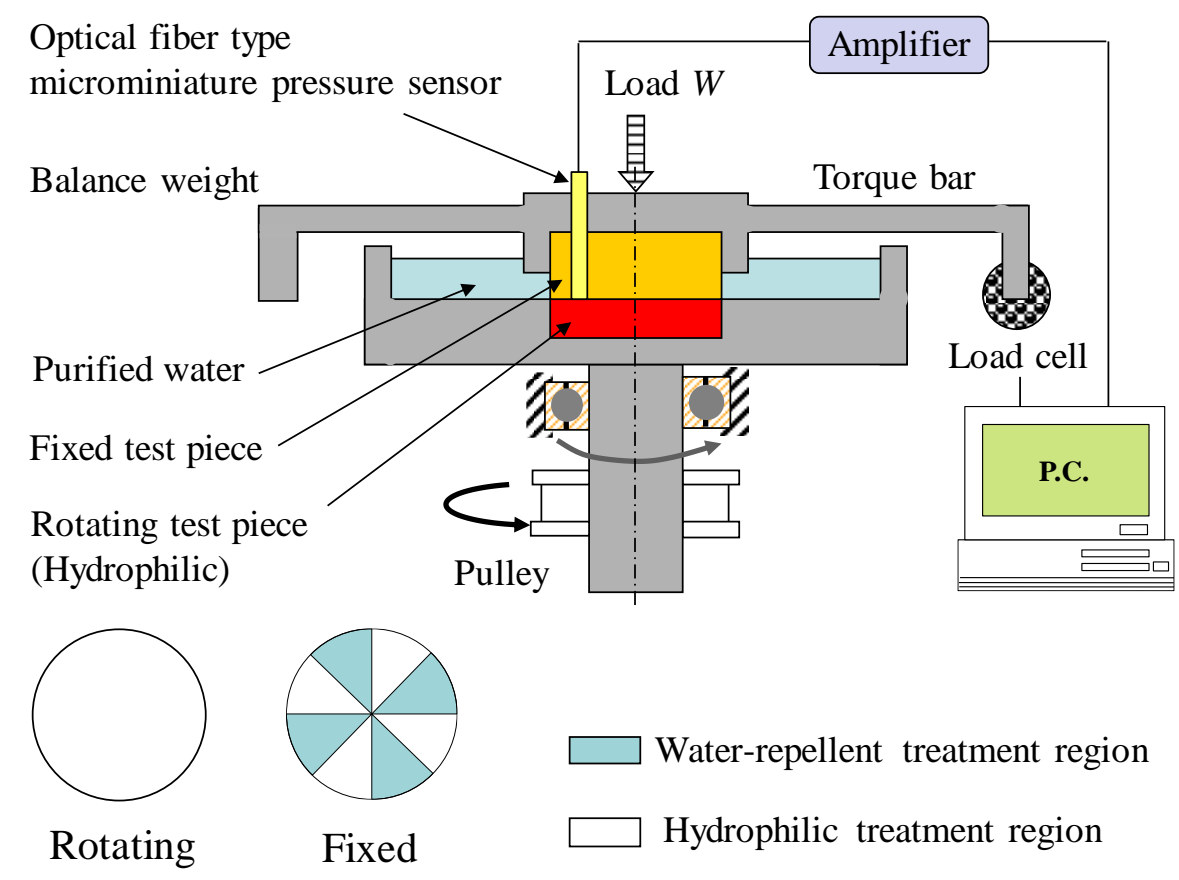

Fig. 1 Schematic diagram of thrust bearing tester. The smooth and flat surfaces of a fixed test piece faces the smooth and flat surface of a rotating test piece fixed at the center of a rotating water tank. The fixed test piece made of soda-lime glass is a 4-WR test piece which four water repellent $(W R)$ regions and four hydrophilic treated $(H T)$ regions are alternately arranged. The surface is almost flat even at the boundary area. However, a $0.2-0.3 \mu \mathrm{m}$ undulation was observed in the diametric direction of $20 \mathrm{~mm}$ including the disk center. The rotating test piece is made of the same material as the fixed test piece and has an entirely hydrophilic surface $(H T)$. The sliding velocity $U$ was set at $0.15 \mathrm{~m} / \mathrm{s}$ and the purified water was used for the lubricant.

撥水処理には表面エネルギーが低く比較的強い撥水性が確認されている，フッ素系撥水剤（パーフルオロアル キルシラザン）を使用した．ソーダガラス製固定試験片（有効直径 $36 \mathrm{~mm} ，$ 厚さ $5 \mathrm{~mm}$ ）への部分撥水面（図 2 参 照）の作製手順は以下の通りである. 先ず, 精製水中で超音波洗浄したガラス円板の試験面をプラズマイオンボ ンバーダにより全面親水処理した後，スピンコーターを用いて全面を撥水処理し， $80^{\circ} \mathrm{C}$ 恒温槽内で 1 時間乾燥 させた. 次に, そのようにして得られた試験面上の, 撥水性を残したい扇状部分を微粘着性の加工工程用極薄シ 一トでマスキングして親水処理を行うことで，例えば図 2 中に示したような，撥水処理部（WR） と親水処理部 (HT) が円周方向に交互に配置された扇状撥水型固定試験片を作製できるが，マスキング前後での静的接触角の 変化は認められなかった．各試験片は，超音波洗浄と乾燥の後にデシケーター内に保存して用いた.

図 2(b)には，撥水領域(b: $\left.\theta \doteqdot 110^{\circ}\right)$ と親水領域(c: $\left.\theta \doteqdot 10^{\circ}\right)$ 上での水滴（30mg）の写真ならびに静的接触角 $\theta$ の違 いを示してあるが, 両領域の境界での幾何学的な段差は認められなかった. しかし, 撥水処理領域の算術平均粗 さは $R_{a} \fallingdotseq 6 \mathrm{~nm}$ であり親水処理領域の $R_{a} \fallingdotseq 4 \mathrm{~nm}$ よりわずかに大きく, また, $20 \mathrm{~mm}$ の測定範囲では $0.2 \sim 0.3 \mu \mathrm{m}$ 程 度の微小なうねりが観測されている，なお，同じうねりを有する相手面となる回転試験片は固定試験片と同じソ 一ダガラス製であり，全面に親水処理 $\left(H T: \theta \doteqdot 10^{\circ}\right)$ を施して用いた.

ところで, 前報において（竹内, 2013), 全面を親水処理した固定試験片では, 扇状撥水型固定試験片で見られ たような荷重の違いによる有意な潤滑膜厚の差は認められないものの, 試験片のうねりが原因と考えられる（中 村, 2002), 増速に伴うわずかな膜厚の増加が確認されていた。しかし, 全面親水型固定試験片での摩擦係数は軽 荷重域でも高く, 増荷によって発生する固体接触により急増するのに対し, 扇状撥水型固定試験片での摩擦係数 は $W=100 \mathrm{~N}$ においても低く安定し，表面の損傷は皆無である等，部分的に扇状撥水部を設けることの優位性も既 に明らかになっている（竹内，北邑，2011）。本報で使用した試験片は，それらと同種のガラス試験片である. 
さて，第 1 章で示した本軸受の作動メカニズムの検証のためには（竹内，北邑，2011）（竹内，2013），摺動中 に発生する軸受の圧力を実測する必要がある. ここでは, 直径 $1.6 \mathrm{~mm}$ の光学ファイバー型圧力センサ（株式会社 レーザー計測，FOP-M）を，図 2(a)に示す 4 扇撥水固定試験片（4-WR）の圧力測定位置に，その先端が潤滑面と 一致するよう設置した. 測定位置は, 半径方向については等価半径 $R_{E}=13 \mathrm{~mm}$ とし, 円周方向に対しては, 撥水処 理部から親水処理部への境界から回転試験片の回転方向下流側の $\varphi=11$ 位置（親水領域入口）とし，センサとセ ンサ挿入口にはプラズマイオンボンバーダにより親水処理を施した.

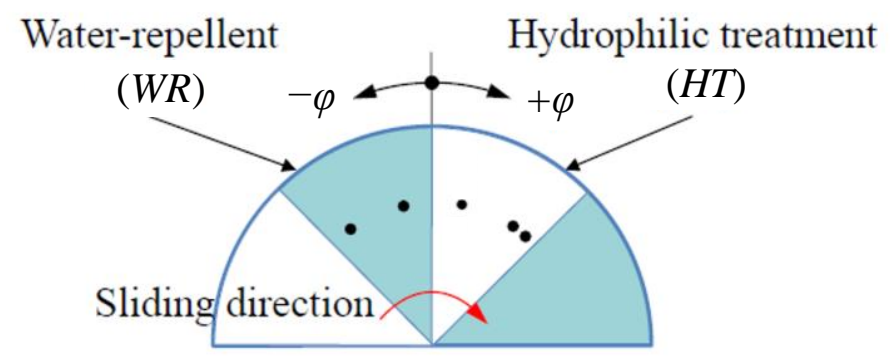

(a) Four section water-repellent bearing (4-WR) Measurement positions are shown with circle

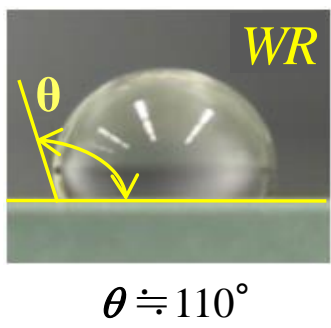

(b) Water-repellent part

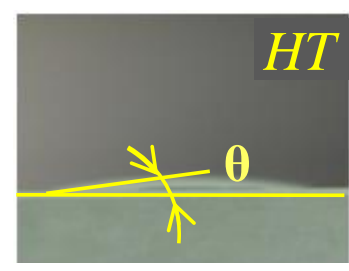

$$
\theta \doteqdot 10^{\circ}
$$

(c) Hydrophilic part

Fig. 2 Pressure measurement positions on fixed test piece and contact angle of water drop. The optical fiber type pressure sensor with a small size (1.6mm in diameter) is used for the pressure measurement. Main pressure measurement position is a point $\left(R_{E}=13 \mathrm{~mm}\right.$ and $\left.\varphi=11^{\circ}\right)$. Reference measurement positions in the circumferential direction are located at five points $\left(\varphi=-34^{\circ},-\right.$ $11^{\circ},+11^{\circ},+34^{\circ}$ and $\left.+40^{\circ}\right)$. Photographs of (b) is a water drop on the water-repellent $(W R)$ region $\left(\theta \doteqdot 110^{\circ}\right)$ and (c) is a water drop on the hydrophilic treatment $(H T)$ region $\left(\theta \doteqdot 10^{\circ}\right)$.

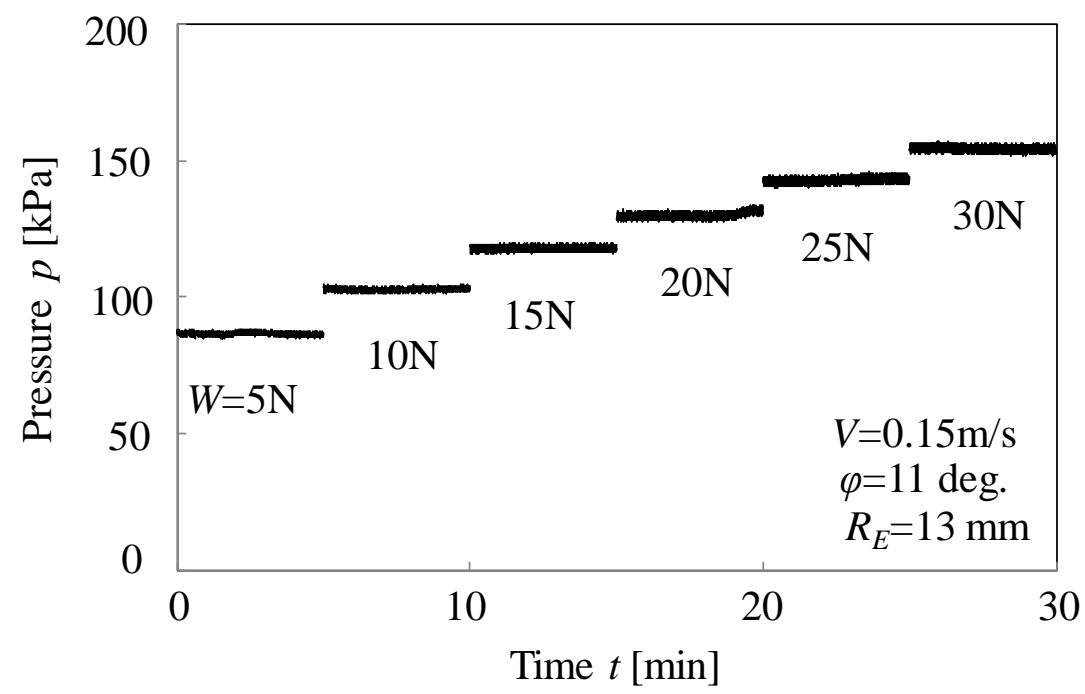

Fig. 3 Pressure measurement example at the point $\left(R_{E}=13 \mathrm{~mm}\right.$ and $\left.\varphi=11^{\circ}\right)$. The generated pressure increases almost in proportion to the applied load after increasing to $p \fallingdotseq 85 \mathrm{kPa}$ at $W=5 \mathrm{~N}$. The pressure for each load is stable. 
また，すべり方向（円周方向）での圧力の発生状態（圧力分布）を知るために，別な固定試験片の $R_{E}$ 位置に対 して $\varphi=-34^{\circ},-11^{\circ},+11^{\circ},+34^{\circ}$ そして, 親水処理部から撥水処理部一の境界に近い $\varphi=+40^{\circ}$ の計 5 箇所での圧力測定

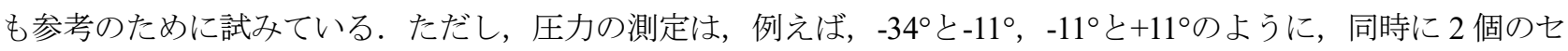
ンサを使用して再現性を確認しながら行った．また， $+40 \circ$ の圧力は別の試験片を用いての結果ではあるが，同時 に測定した $+11^{\circ} の$ 圧力は前記固定試験片での結果とほぼ一致している．ちなみに $\varphi=0^{\circ}$ (境界) は，圧力発生の要 因であるせん断流量の不連続性に強く関与寸る箇所であり，両領域に亘るセンサとセンサ孔部の配置は，発生圧 力を大きく変化させる可能性があるため, 実験では, その位置へのセンサの配置は避け, 境界の両隣 $\left(\varphi= \pm 11^{\circ}\right)$ での圧力から境界圧力 $p_{M}$ を推定することにした。

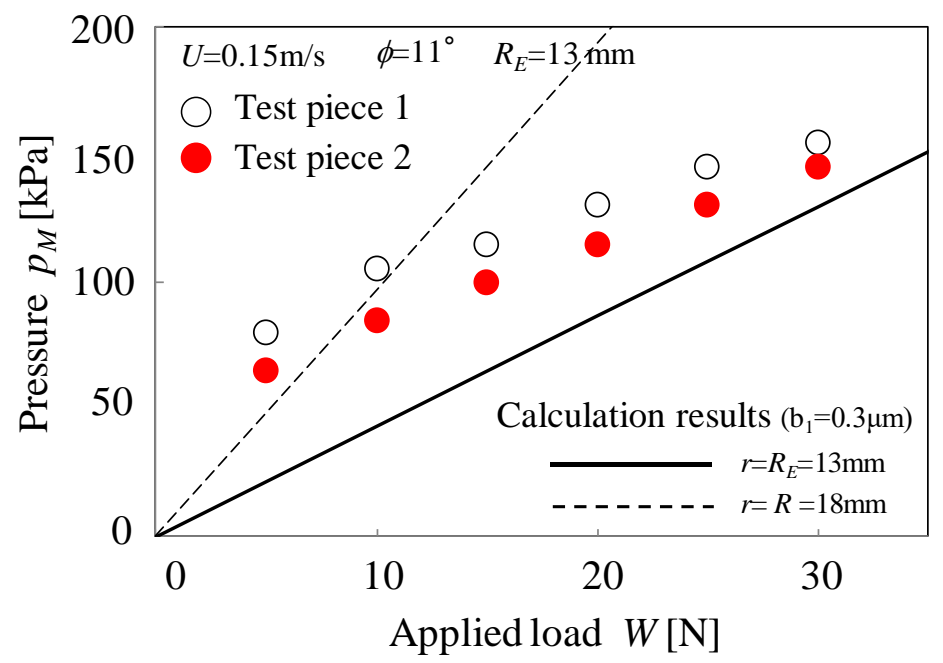

Fig. 4 Pressure measurement results performed with two test pieces. The satisfactory repeatability of generated pressure on loading is identified. Incidentally, the pressure $p$ measured here is the pressure on the downstream side of $\varphi=+11^{\circ}$ from the boundary of the water repellent/hydrophilic treatment regions. However, as can be seen from figure 5, this pressure is almost the same as the pressure $p_{M}$ at the boundary $\left(\varphi=0^{\circ}\right)$ between both treatment parts. The lines in the figure are the calculation results of the infinite width bearing approximation shown for the reference. The solid line is the pressure $p_{M}$ at $r=R_{E}=13 \mathrm{~mm}$ and the broken line is for the effective radius $r=18 \mathrm{~mm}$ of the specimen.

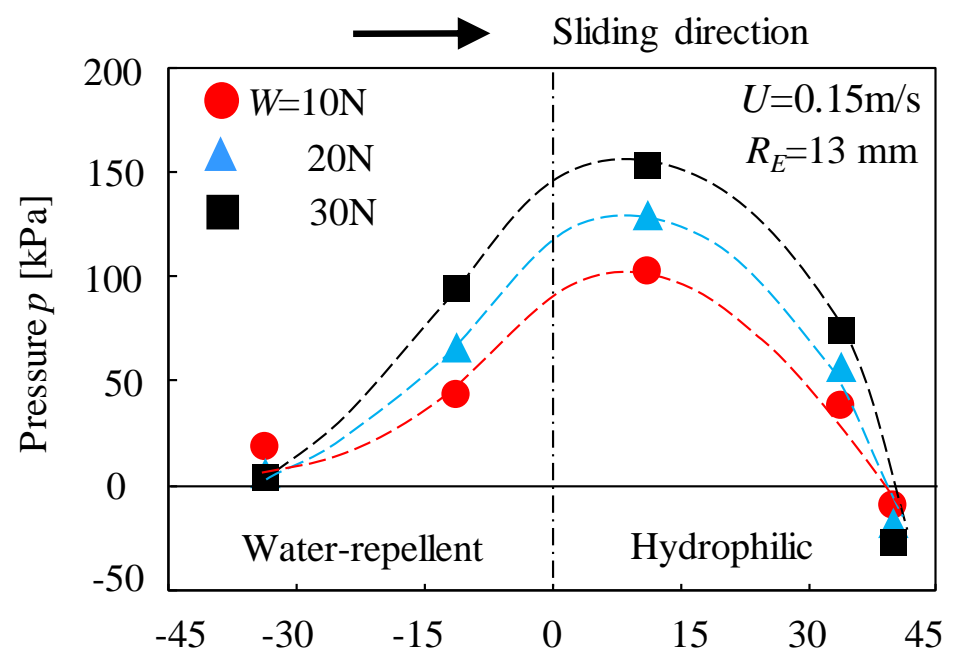

Angular position in circumferential direction $\varphi$ [deg.]

Fig. 5 Pressure measurement results in circumferential direction. The pressure in the circumferential direction increases on the water repellent side and decreases on the hydrophilic side. This pressure distribution is similar to that of the pressure model shown in figure 7 and of the conventional step bearing. In addition, the pressure at the boundary between both regions is considered to be almost the same as the pressure at $\varphi=+11^{\circ}$. 
図 3 には, 荷重 $W$ 5 30N（平均圧力 $p_{m}$ は 5 30kPa）の範囲で $5 \mathrm{~N}$ 刻みで階段状に増加させた場合の圧力の測 定例 $\left(R_{E}=13 \mathrm{~mm}, \varphi=11\right.$ 位置) を示してある. 各荷重での保持時間は摩擦が十分に安定する 5 分とした. また, $R_{E}=13 \mathrm{~mm}$ での寸べり速度は $U=0.15 \mathrm{~m} / \mathrm{s}$ であった. 発生圧力は, $W=5 \mathrm{~N}$ で $p \fallingdotseq 85 \mathrm{kPa}$ まで上昇した後は荷重にほぼ 比例して増加し，各何重での圧力は安定している．図４には，同種の別軸受（試験片 2）について調べた発生圧 力の測定值も併せて示してあるが，両者は $\pm 3 \%$ × $13 \%$ の圧力差内にあり，一致した傾向を示している.

ここで測定した圧力 $p$ は, 上述のように, 等価半径 $R_{E}=13 \mathrm{~mm}$ で, 撥水・親水処理部の境界から $\varphi=11^{\circ}$ 下流側で の圧力であるが，これは，図 5 のすべり方向 (円周方向) の圧力分布に例示すように, 両処理部の境界 $\left(\varphi=0^{\circ}\right)$ での圧力 $p_{M}$ とほぼ同じであると判断してよい，ちなみに，円周方向の圧力は，撥水処理側で上昇し，親水処理側 で下降しており, 後述の図 7 に示寸発生圧力モデル, ならびに, 従来のステップ軸受と類似な圧力分布となる（橋 本他, 1985).ただし, 実測された圧力のピークは, 撥水領域と親水領域の境界ではなく,わずかに親水領域内に 入った所で現れている，この原因については，例えば慣性力の影響（橋本他，1985）も挙げられるが，本軸受の 場合，全面撥水後に非マスキング部分を親水化処理する際に，撥水領域との境界近くの親水側に残った弱撥水部 が影響した可能性が高い. この場合の最大圧力位置は, 弱撥水領域と親水領域の境界になる（竹内, 2016). とこ ろで, 図 5 の $\varphi=+40$ 位置では, わずかな負圧が観測されており, 潤滑面への精製水の供給に寄与しているものと 判断できる.

ところで, 図 6 中には, 図 3 の圧力測定時に計測された摩擦係数をム印で示してあるが, その挙動はセンサ挿 入用孔を持たない同種試験片での結果 (破線で示す) と一致し, また, 図中に例示した $W=30 \mathrm{~N}$ での摩擦係数の時 間変化からも分かるように安定しており，孔の影響は認められない，なお，同図の横軸は軸受特性数， $\eta N / p_{m}(\eta$ は精製水の粘度, $N$ は毎秒回転数, $p_{m}$ は平均面圧）である.

本スラスト軸受については，摩擦特性に及ぼす撥水性（水滴の静的接触角 $\theta$ の違い）の影響や，超音波法によ る運転状態での膜厚測定等が既に行われている，そして，撥水性の増大による摩擦特性の改善は，撥水面での流 体のすべりに伴い発生する圧力により支持荷重が増大して, 同じ荷重での膜厚が厚くなることが主要因であり, これによりせん断抵抗が減少して摩擦係数が低下寸ると推定されていた（竹内, 2013). 今回, 膜厚の増大の要因 となる圧力の発生が実際に確認されたことにより，本軸受の基本的特性を従来の軸受理論を基に考察できる可能 性が増したと考える。

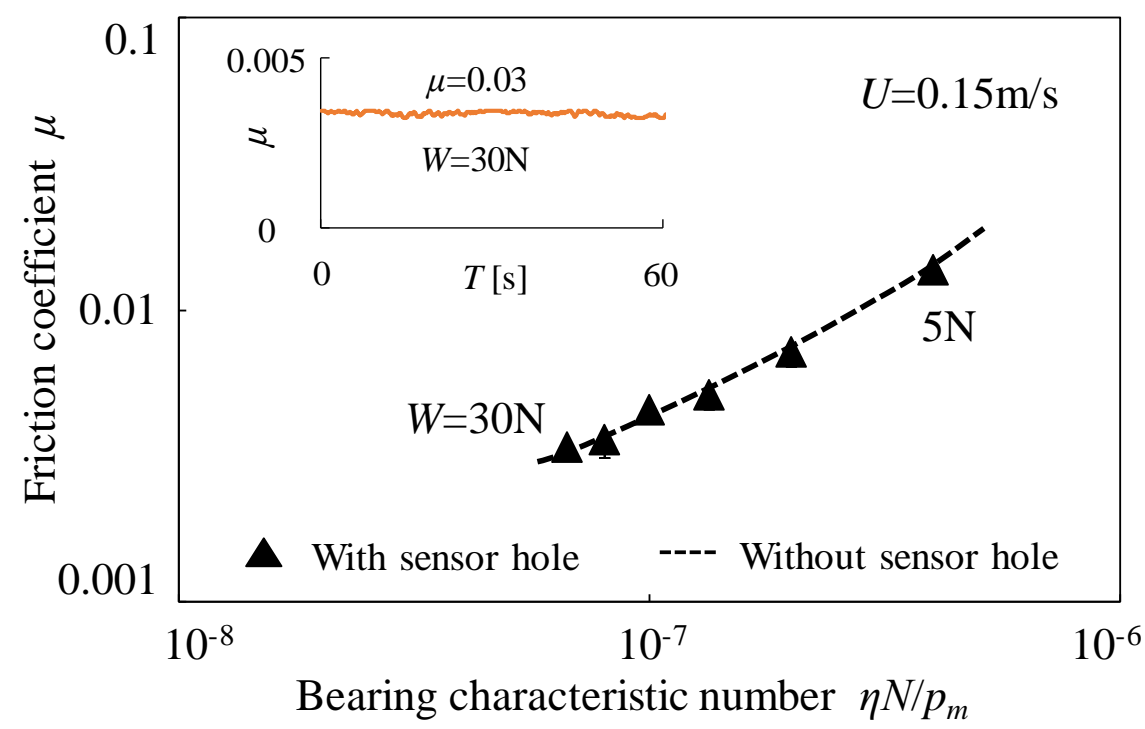

Fig. 6 Bearing characteristic curves with and without sensor hole. The horizontal axis represents the bearing characteristic number $\eta N / p_{m}$ ( $\eta$ is the viscosity of purified water, $N$ is the number of rotations per second, and $p_{m}$ is the average pressure). The friction coefficient measured at the time of pressure measurement is indicated by $\boldsymbol{\Delta}$. The measured friction coefficients almost agree with the curve without a sensor hole shown by the broken line. In addition, it shows low $(\mu=0.003)$ and stable behavior as shown in the illustration in this figure, even under the severe condition of $W=30 \mathrm{~N}$. Therefore, it can be judged that the lubrication property is not influenced with the sensor hole. 


\section{3.＼cjkstart部分スリップ型フラットスラスト軸受の無限幅軸受近似}

本報では，半径方向の流れを無視した最も単純な無限幅軸受近似モデルを考える. 図 7 は，壁面スリップが発 生する領域と，発生しない領域での，速度分布の概略図であり，圧力流れは，それら 2 つの領域でのせん断流量 の不連続性を補うために誘起される，なお，図７の左側に示すスリップ速度 $u_{s}$ は，スリップ長さ $b$ に依存したせ ん断流れの速度 $u_{s s}$ と, $u_{s s}$ と反対方向に向から圧力流れにより誘起されるすべり速度 $u_{s p}$ の和である. したがって, 同図に示寸ように，固定壁面にスリップ $u_{s}$ が生じるときの流速 $u$ は次式で与えられる.

$$
u=U+\left(u_{s}-U\right) \frac{z}{t}+\frac{1}{2 \eta} \frac{d p}{d x}\left(z^{2}-t z\right)
$$

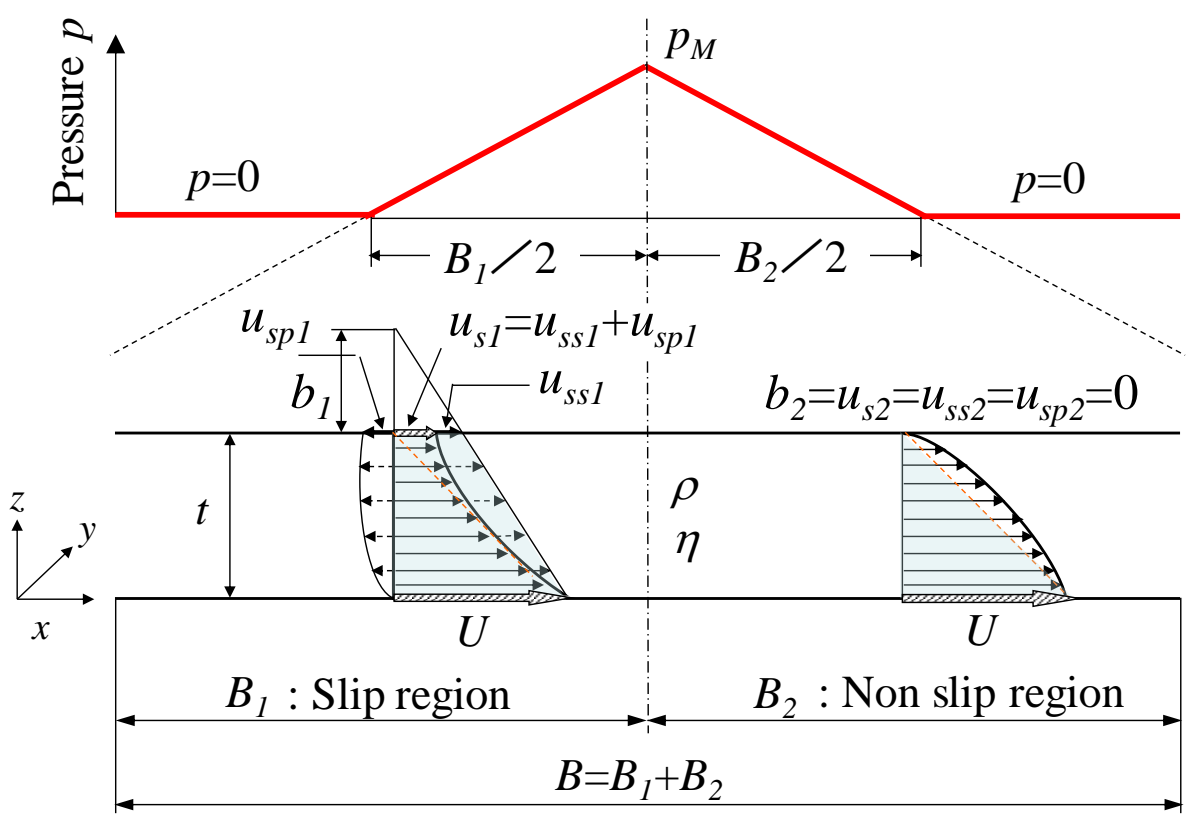

Fig. 7 Infinite width bearing approximation model of partial slip flat thrust bearing. The slip velocity $u_{s}$ shown in the slip region in this figure is the total velocity of the shear flow $u_{s s}$ depending on slip length $b$ and of the slip velocity $u_{s p}$ influenced by pressure flow generated to the opposite direction of $u_{s s}$.

ここでは, 本部分スリップ軸受の最も基礎的な特性を調べるために, スリップ速度 $u_{s}$ が壁面のせん断応力に比 例し，一定のスリップ長さを持つとした，最も単純なモデルを仮定した（Chooetal., 2007a）。ここで，粘度 $\eta$ を 一定とした場合の壁面スリップを考慮した 2 次元の修正レイノルズ方程式は，流量の連続性より以下のように導 かれる（竹内, 2013）。

$$
\frac{d}{d x}\left(\alpha_{p} t^{3} \frac{d p}{d x}\right)=6 \eta U \frac{d}{d x}\left(\alpha_{s} t\right)
$$

ただし， $\alpha_{p}=1+3 b /(b+t) ， \alpha_{s}=1+b /(b+t)$ である.

本スラスト軸受のように，先すぼまり部を持たない平坦で平行な軸受面の，固定壁面側でスリップが発生する 図 7 の場合には, 入り口側のスリップ領域と出口側の非スリップ領域での流量の連続性から, それら境界で発生 する圧力 $p_{M}$ は次式のように求まる. なお, 本基礎特性の解析では, 最も単純な Half-Sommerfeld の境界条件を採 用し，負圧部分は大気圧 $(p=0)$ と仮定している.

$$
p_{M}=3 \frac{\alpha_{s 1}-\alpha_{s 2}}{\alpha_{p 1} B_{2}+\alpha_{p 2} B_{1}} \frac{\eta U}{t^{2}} B_{1} B_{2}
$$


ただし， $\alpha_{s 1}$ と $\alpha_{s 2}$ は長さ $B_{1}$ の領域（以後， $B_{1}$ 領域と記す）と長さ $B_{2}$ の領域（以後， $B_{2}$ 領域と記す）のそれぞれの 領域でのせん断流れに対する修正係数， $\alpha_{p 1}$ と $\alpha_{p 2}$ は圧力流れに対する修正係数である. なお，本スラス卜軸受の ように出口側 $B_{2}$ でのスリップがない $\left(b_{2}=0\right)$ 場合には, $\alpha_{s 2}=\alpha_{p 2}=1$ となる. また 2 面が平行な無限幅軸受の場合 には，せん断流量は入口側と出口側の各領域のいたる所で一定であるため，圧力流れの流量も一定になり，圧力 勾配 $\mathrm{d} p / \mathrm{d} x$ も各領域で一定 $\left\{B_{1}: p_{M} /\left(B_{1} / 2\right), B_{2}: p_{M} /\left(B_{2} / 2\right)\right\}$ になる.

したがって, 幅 $B=2 \pi r / n$, 速度 $U=2 \pi r N, \beta=B_{1} / B, \quad r$ を任意半径, $n$ を単位軸受の個数（例えば, 4 扇撥水軸受 では $n=4), N$ を毎秒回転数(rps) として, $n$ 個の単位軸受を持つ本軸受の支持荷重 $W$ を求めると次式のようにな る（竹内, 2013）.

$$
W=\frac{3}{2} \frac{\beta(1-\beta)\left(\alpha_{s 1}-1\right)}{\alpha_{p 1}(1-\beta)+\beta} \frac{\pi^{3} R^{4} \eta N}{t^{2} n}
$$

例えば図 4 中には， 4 扇軸受 $(\beta=0.5)$ について計算した，支持荷重 $W$ とスリップ・非スリップ領域の境界での 圧力 $p_{M}$ の関係を示してある. 実線は等価半径 $R_{E}=13 \mathrm{~mm}$ （実験での圧力測定位置）での圧力，破線は参考のため に示した固定試験片の有効半径位置での圧力である. 荷重 $W$ に対する各 $R$ (したがって速度 $U$ ) での計算圧力 $p_{M}$ は, 前報に示したように（竹内, 2013), 式 (4) 中の修正係数に $\alpha_{p l}=1+3 b_{I} /\left(b_{I}+t\right), \alpha_{s l}=1+b_{I} /\left(b_{1}+\mathrm{t}\right)$ を代入し, 膜厚 $t$ に関する 3 次式を解いて荷重 $W$ に対応する膜厚 $t$ を定め, 式 (3) に代入することで求めている. ただし, 計算 で用いたスリップ長さ $b_{l}$ は, 図 8 の $\theta \fallingdotseq 110^{\circ}$ での実験結果に最も近い摩擦特性を示した $b_{l}=0.3 \mu \mathrm{m}$ を採用した. 計 算結果は実験結果同様，支持荷重 $W$ に比例して増加するが，実際の軸受では，半径方向への漏れの影響により外 周近傍の圧力が低下寸るために, 同じ負荷を支持する際の実測圧力は, 実線で示した $R_{E}$ 位置での計算值より高く 現れている.

ところで, 本軸受 (図 1 参照) の摩擦力については, 図 7 に示すように, 正圧発生領域ではせん断流れと圧力 流れの双方の影響を受け，それ以外の領域では前述の境界条件に基づき，全領域が大気圧下の流体で満たされる と仮定してせん断流れのみを考慮する。この場合, 図 3 に示寸扇状単位軸受に対する固定側（上側）での摩擦力 は，スリップが発生する領域 $B_{1}$ と非スリップ領域 $B_{2}$ のそれぞれについて，以下のようになる．まず，スリップ 領域 $B_{1}$ での単位幅当たりの摩擦 $F_{U 1 L}$ は,

$$
F_{U 1 L}=\frac{-B_{1}}{2} \eta\left(\frac{u_{s s 1}-U}{t}+\frac{u_{s 1}-U}{t}+\frac{t}{\eta B_{1}} p_{M}\right)=\left(2-\alpha_{s 1}\right)\left(B_{1} \eta \frac{U}{t}-\frac{t}{2} p_{M}\right)
$$

で与えられる. 領域 $B_{2}$ での単位幅当たりの摩擦 $F_{U 2 L}$ も同様に,

$$
F_{U 2 L}=\frac{-B_{2}}{2} \eta\left(\frac{u_{s s 2}-U}{t}+\frac{u_{s 2}-U}{t}-\frac{t}{\eta B_{2}} p_{M}\right)=\left(2-\alpha_{s 2}\right)\left(B_{2} \eta \frac{U}{t}+\frac{t}{2} p_{M}\right)
$$

となる. したがって, 上側の固定軸受の単位軸受に作用する単位幅当たりの摩擦力 $F_{U L}$ は, 非スリップ領域 $B_{2}$ で は $\alpha_{s 2}=\alpha_{p 2}=1$ となることを考慮すると，

$$
\begin{aligned}
F_{U L} & =F_{U 1 L}+F_{U 2 L}=\left[\left(1-\alpha_{s 1}\right) B_{1}+B\right] \eta \frac{U}{t}-\left(1-\alpha_{s 1}\right) \frac{t}{2} p_{M} \\
& =\left[\left(1-\alpha_{s 1}\right) \beta+1+\frac{3}{2} \frac{\beta(1-\beta)\left(1-\alpha_{s 1}\right)^{2}}{\alpha_{p 1}(1-\beta)+\beta}\right] B \eta \frac{U}{t}
\end{aligned}
$$

と求まる.ここで, 幅 $B=2 \pi r / n$, 速度 $U=2 \pi r N$ として, 1 組のスリップ・非スリップ領域からなる扇状単位軸受の 摩擦を求めて, $n$ 個の扇状単位軸受を有する固定軸受側の摩擦力 $F_{U}$ を導出すると次式のようになる.

$$
F_{U}=\frac{4}{3}\left[\left(1-\alpha_{s 1}\right) \beta+1+\frac{3}{2} \frac{\beta(1-\beta)\left(1-\alpha_{s 1}\right)^{2}}{\alpha_{p 1}(1-\beta)+\beta}\right] \frac{\pi^{2} R^{3} \eta N}{t}
$$




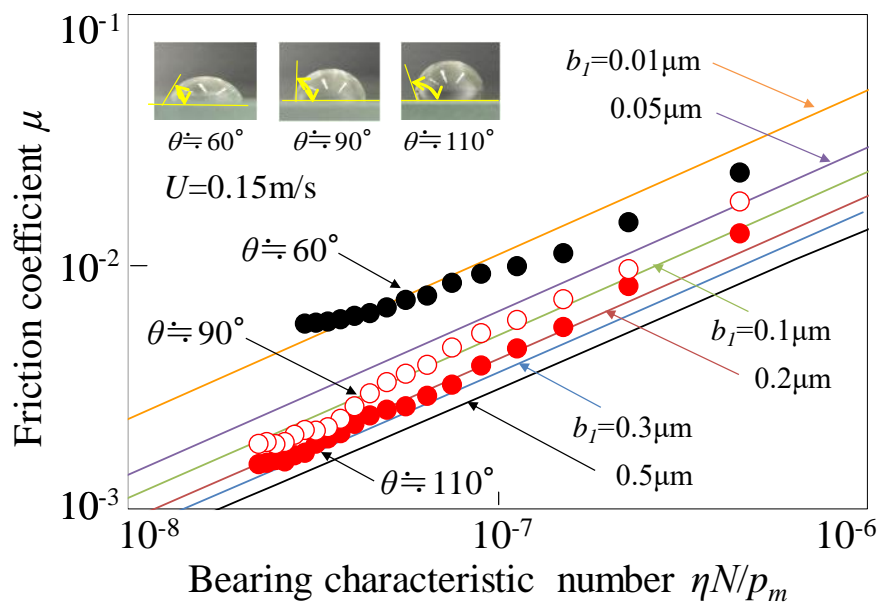

Fig. 8 Influence of static contact angle $\theta$ of water droplet in water-repellent region on bearing characteristic curves (3-WR). In the figure, the relationship shown in the previous report between the bearing characteristic number (load $W=5$ to $100 \mathrm{~N}$ ) and the measured friction coefficient $\mu$ using the partial water-repellent thrust bearings with three fan-shaped unit bearings, are plotted. The velocity gradient of the shear flow becomes smaller and the film thickness under the same supporting load is increased, as the slip length increases and the surface where slip is easy to occur (static contact angle $\theta$ is large). Therefore, the coefficient of friction tends to be lower. The fine lines in the figure are the calculation results of the infinite width bearing approximation shown for reference.

図 8 には，既報の 3 扇部分撥水スラス卜軸受について求めた（竹内，北邑，2011），軸受特性数（荷重 $W=5 \sim$ $100 \mathrm{~N} ）$ と固定試験片の摩擦係数 $\mu$ の実測結果をプロットしてある. 前述のように, 図 7 の $B_{1}$ 領域でのスリップ 長さ $b_{1}$ が大きく，壁面滑りが発生し易い面（静的接触角 $\theta$ が大きな面）であるほど（Voronov et al., 2006），せん 断流れの速度勾配が小さくなり，同じ荷重を支持する際の膜厚が厚くなるため，摩擦係数は低く現れたと考えら れる．同図中には，上述した無限幅軸受近似での計算結果（各 $b_{1}$ 毎の実線で示す）を参考のために示した．スリ ップ長さ $b_{1}$ が大きな面ほど摩擦係数は低くなっており，実測結果とほぼ一致した傾向を示している.

\section{4.＼cjkstart無限幅軸受近似による部分スリップ型フラットスラスト軸受の基礎潤滑特性の一考察}

以上述べた計算結果は，軸受外周への漏れを考えない無限幅軸受近似によるものではあるが，実験で得られた 傾向の説明はできており，これにより，部分撥水（スリップ）型フラットスラスト軸受の基礎潤滑特性の考察が 可能なことを示唆している.

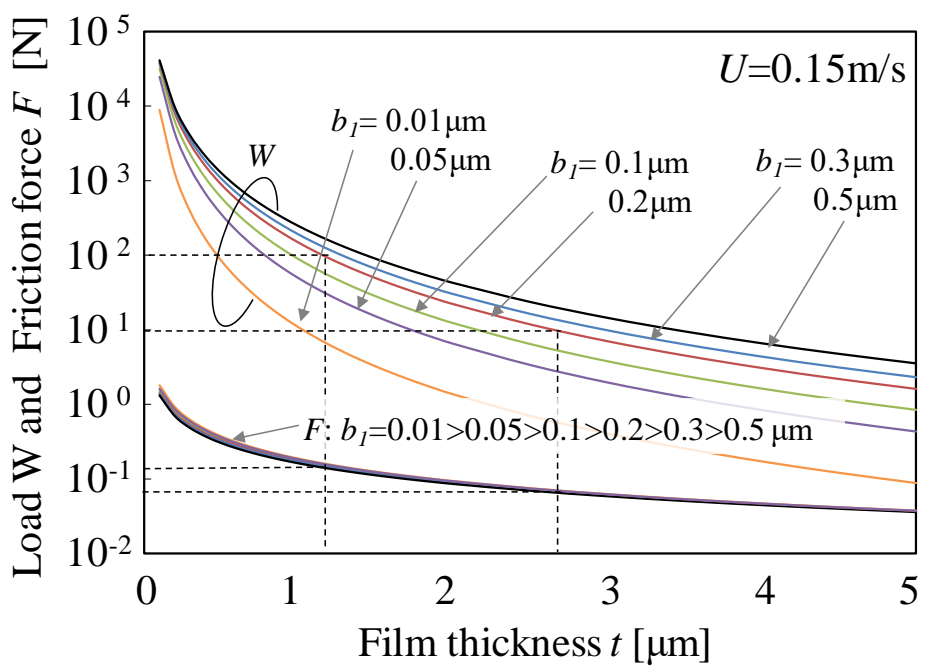

Fig. 9 Effect of slip length $b_{1}$ in the $B_{1}$ region on load capacity $W$ and frictional force $F$ at each lubrication film thickness $t$. The effect of slip on the load capacity is remarkable and the load capacity increases rapidly for the larger slip length $b_{1}$, but the degree of increase becomes weak gradually in the case of larger $b_{1}$ and thinner film thickness $t$. On the other hand, the effect of slip length on friction force is hardly recognized, but the friction force tends to decrease as the slip length increases. In addition, the degree of increase in friction force relative to the decrease in film thickness is weaker than the degree of increase in load capacity. 


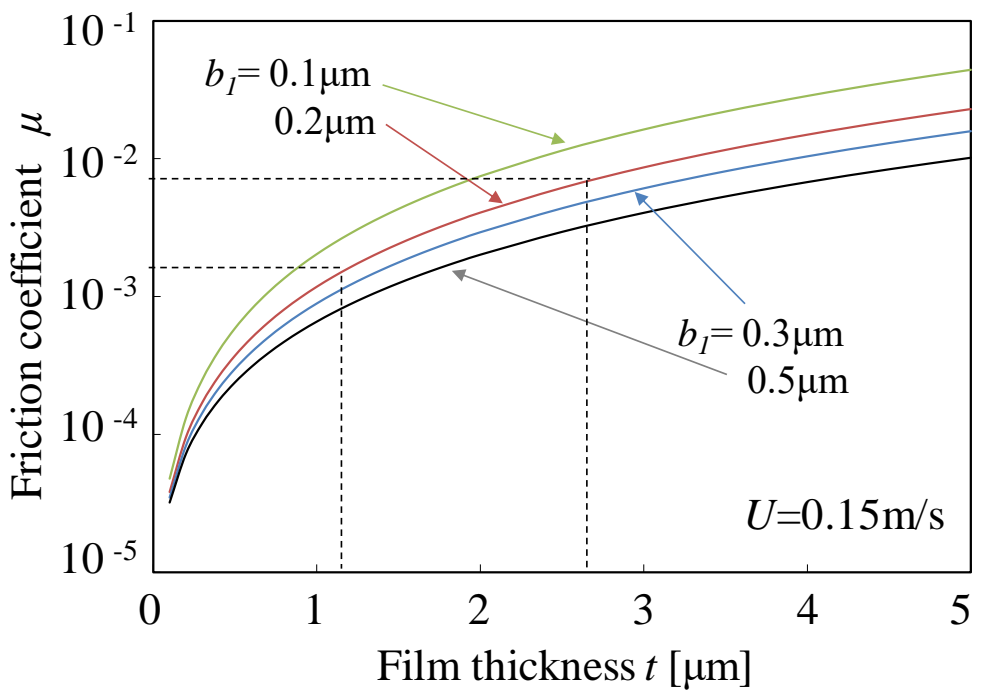

Fig. 10 Effect of slip length $b_{1}$ on the friction coefficient for each lubrication film thickness $t$. The friction coefficient $\mu$ decreases as the film thickness $t$ becomes thinner, especially it decreases rapidly in the thin film region. However, the difference in friction coefficient due to the difference in slip length $b_{1}$ becomes smaller in such region.

図 9 には，各膜厚 $t$ での支持荷重 $W$ と摩擦力 $F$ に及ぼす $B_{1}$ 領域でのスリップ長さ $b_{1}$ の影響を示す. 全面が非 スリップ $\left(b_{1}=0\right)$ の潤滑面では圧力は発生しないことを考えると，支持荷重に対するスリップの影響は顕著であ り，（1）スリップ長さ $b_{1}$ が長いほど支持荷重は増大する。（2）増大の程度は $b_{1}$ の増加とともに，そして（3） 膜厚の減少と共に徐々に緩慢になる。一方，(4) 摩擦力に対するスリップ長さの影響は仮定したスリップ長さの 範囲 $\left(b_{1}=0.01 \sim 0.5 \mu \mathrm{m}\right)$ ではほとんど認められないが，（5）スリップ長さが長いほど摩擦力は低くなる傾向を示 す. また（6）膜厚の減少に対する摩擦力の増加の程度は支持荷重の増加の程度に比べて緩慢である.このため, 困 10 のように摩擦係数 $\mu$ は膜厚 $t$ の減少と共に低下し，特に薄膜領域で急激な低下を示すが，（7）薄膜領域で はスリップ長さ $b_{1}$ の違いによる摩擦係数の差は小さくなる。これら特性の内（1）と（5）については，スリッ プ流れ $u_{S S}$ の発生による $B_{1}$ 領域でのせん断流量の増加と, 同領域での速度勾配の減少が要因である。 また，（6） の傾向については，支持荷重 $W$ と摩擦力 $F$ に対する膜厚 $t$ の効き方の違いから明らかである.

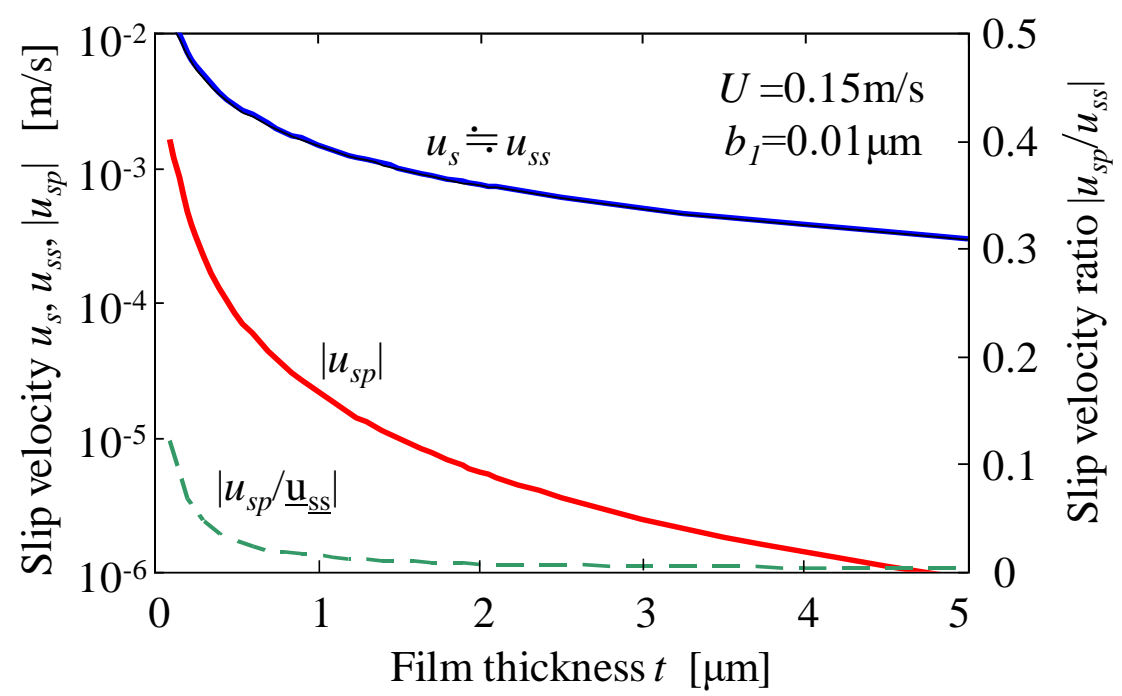

Fig. 11 Detail of slip velocity in bearing with slip region of $b_{1}=0.01 \mu \mathrm{m}$. The slip velocity $u_{s}$ and its elements which are the shear flow component $u_{s s}$ and the pressure flow component $u_{s p}$ are shown in the figure. Since the pressure generated in the bearing with a small value of $b_{1}(=0.01 \mu \mathrm{m})$ in the $B_{1}$ region is low, the influence of the pressure flow $u_{s p}$ on the slip velocity $u_{s}$ hardly appears as shown in the figure. Therefore, $u_{s}$ almost agrees with $u_{s s}$.

それらを含む本軸受の基礎特性を知る上で，壁面でのスリップ速度の検討は重要になる．図 $11 〜 13$ には，スリ ップ速度 $u_{s}$ と, その内容であるせん断流れ成分 $u_{s s}$ や圧力流れ成分 $u_{s p}$ の大きさに対するスリップ長さ $b_{1}$ の影響を 
示してある. $B_{1}$ 領域での $b_{1}$ の值が小さな軸受面 $\left(b_{1}=0.01 \mu \mathrm{m}\right)$ での発生圧力は低いため, 図 11 中に示すように, スリップ速度 $u_{s}$ に対する圧力流れ $u_{s p}$ の影響はほとんど現れない. このため $\left(\left|u_{s p}\right| u_{s s} \mid<0.1\right)$ となり，矮は $u_{s s}$ とほぼ 一致する．これに対し，スリップ長さが $b_{1}=0.5 \mu \mathrm{m}$ と大きな軸受面（図 13）では発生圧力が高くなるため，せん 断流れのスリップ $u_{s s}$ を抑制する向きの上流側への圧力流れ成分 $u_{s p}$ が増大して $\left(\left|u_{s p} / u_{s s}\right|>0.1\right), B_{1}$ 領域でのスリッ プ速度 $u_{s}$ が $u_{s s}$ に比べて大きく低下するようになる。このため，上述の（2）で示したように，大きなスリップ長 さを有する軸受では $b_{1}$ の更なる増大に対する支持荷重の増加は緩慢になる。また，発生圧力が高い薄膜領域ほど 圧力流れの影響が顕著になるため, 上述の（3）に示したように，この領域での支持荷重に対するスリップ長さ の違いは，厚膜領域ほど顕著には現れなくなる.

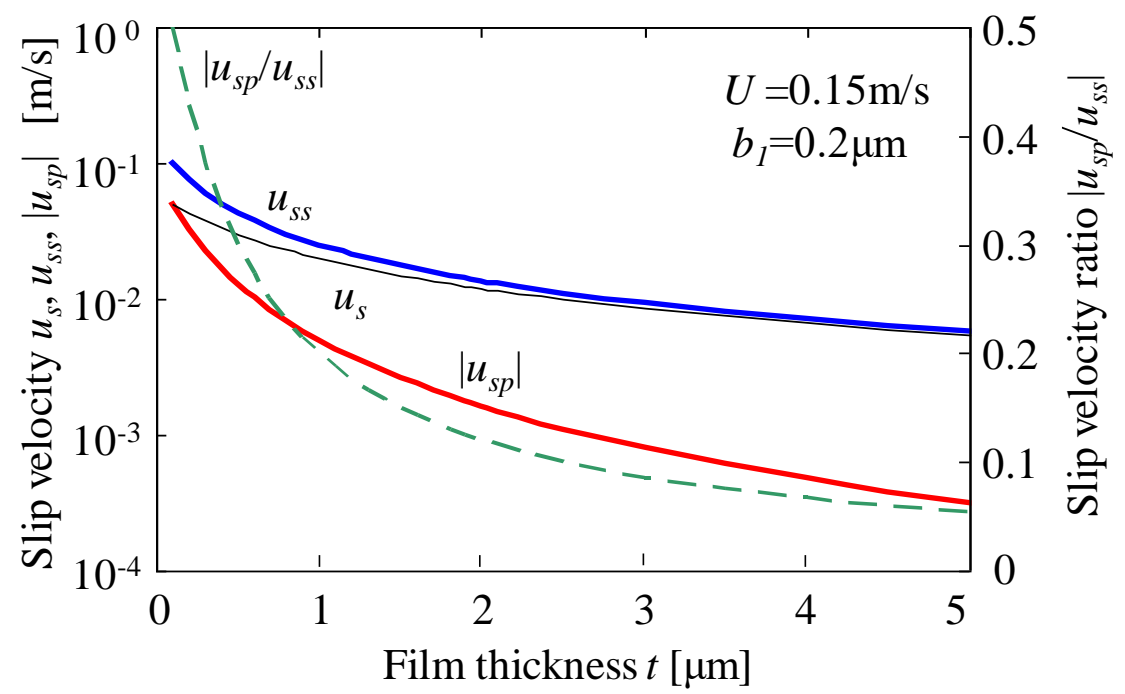

Fig. 12 Detail of slip velocity in bearing with slip region of $b_{1}=0.2 \mu \mathrm{m}$.

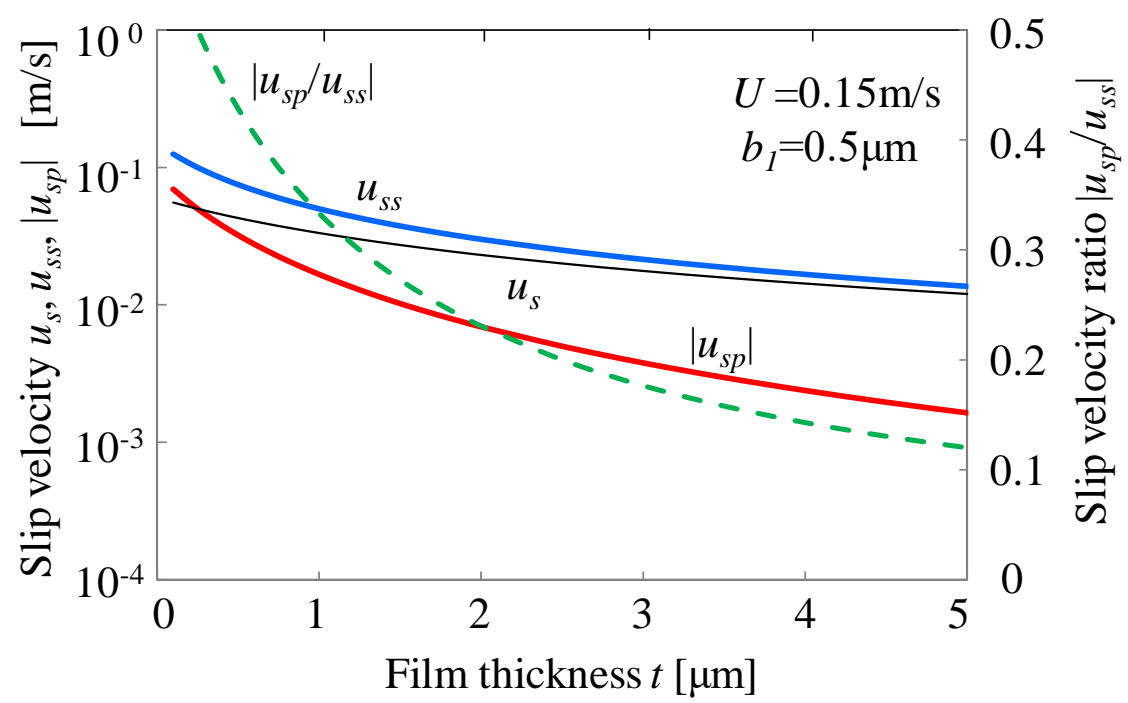

Fig. 13 Detail of slip velocity in bearing with slip region of $b_{1}=0.5 \mu \mathrm{m}$. On a bearing surface with a large slip length of $b_{1}=0.5 \mu \mathrm{m}$, the generated pressure is high, especially in the thin film region. Therefore, the pressure flow component $u_{s p}$ to the upstream side which is the direction of reducing the slip of shear flow component $u_{s s}$ is increased. As a result, the slip speed $u_{s}$ in the $B_{1}$ region becomes considerably lower than $u_{s s}$.

ところで本軸受では，図中にも示したように $\left|u_{s p}\right|$ が $u_{s s}$ を上回ることはなく，いずれの膜厚やスリップ長さにお いてもスリップの効果は支持荷重を増大させる方向に作用する. そして，スリップ長さが比較的小さな面であっ ても支持荷重を得ることができるため，例えば，低回転や高荷重のように薄膜領域で運転する軸受では，運転中 
に撥水性が徐々に低下したとしても支持荷重の減少は少なく, 安全な運転状態を維持できる可能性がある。ちな みに，ジャーナル軸受のように先すぼまり領域を持つスリップ軸受では，〈さび効果により発生する圧力が大き く, せん断流れとは逆向きの圧力流れでのスリップの影響が強く現れるため, 従来の非スリップ軸受に比べて支 持荷重を低下させることもある（Fortier and Salant, 2005）.

図 14〜16には摩擦力 $F$ に対するスリップの影響を示してある. 図には, 軸受全面をスリップ長さ $b_{1}=b_{2}$ のスリ ップ面（全面撥水に相当）とした場合の摩擦力 $F_{W R}$, 軸受全面を $b_{1}=b_{2}=0$ （全面親水に相当）とした場合の摩擦力 $F_{H T}$ ，そして部分スリップ型フラットスラスト軸受 $\left(b_{1}, b_{2}=0\right)$ の各領域 $\left(B_{1}, B_{2}\right)$ でのせん断流れだけを考慮した 場合の摩擦力 $F_{S H}$ の計算結果を, 参考のために示してある. 本軸受の摩擦力 $F$ は, 例えば図 15 に示寸ように, $F_{H T}$ と $F_{W R}$ の間に現れるが， $b_{1}=0.2 \mu \mathrm{m}$ （図 $15 ）, b_{1}=0.5 \mu \mathrm{m}$ （図 16）と比較的大きなスリップが発生する軸受でも, 圧力流れの影響は小さく，固定側軸受の摩擦力 $F$ は圧力流れを無視した場合の摩擦力 $F_{S H}$ とほぼ同じ值を示す.

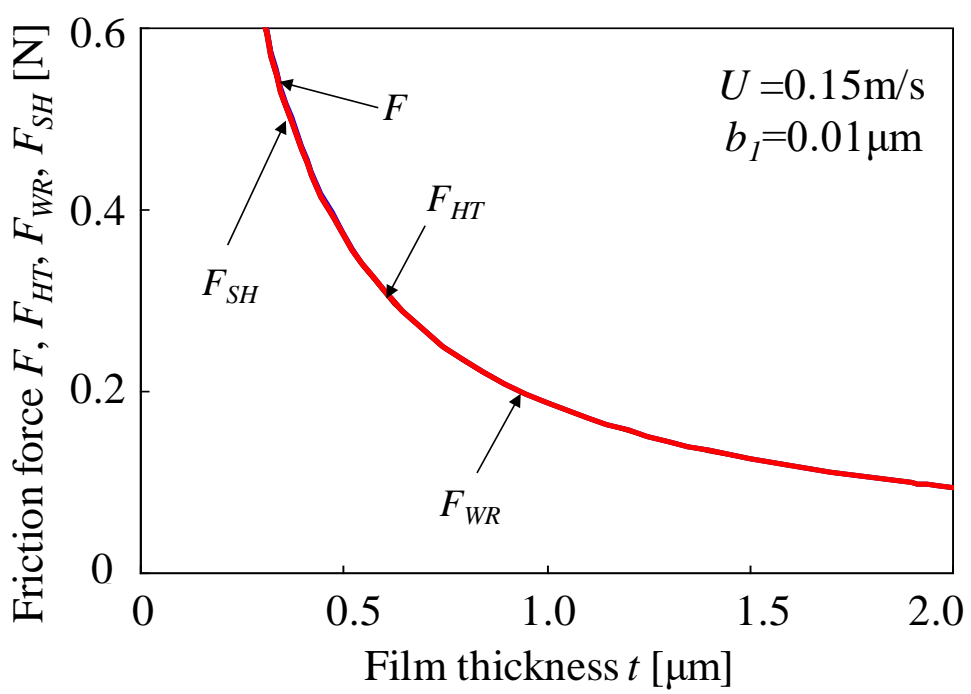

Fig. 14 Influence of slip on the friction force $F\left(b_{1}=0.01 \mu \mathrm{m}\right)$. The influence of slip on the friction force $F$ for a bearing with a small slip length of $b_{1}=0.01 \mu \mathrm{m}$ does not appear. The friction force $F_{W R}$ when the entire bearing surface is a slip surface with slip length $b_{1}$, the friction force $F_{H T}$ when the entire bearing surface is non slip surface with $b=0$ and the frictional force $F_{S H}$ for partially slip bearing considering a shear flow only have almost the same value.

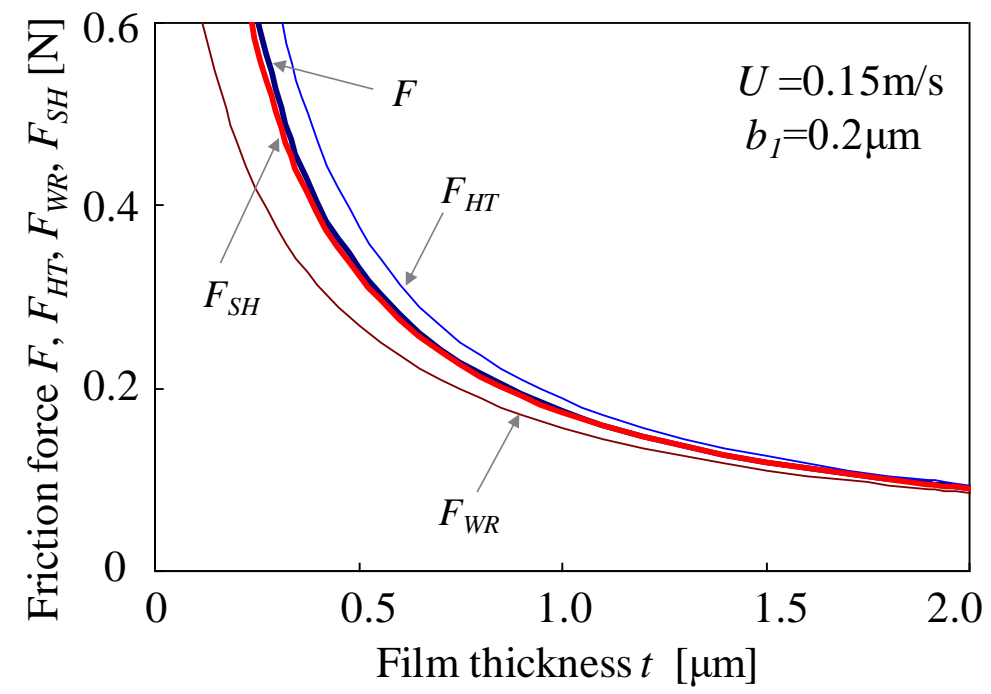

Fig. 15 Influence of slip on the friction force $F\left(b_{1}=0.2 \mu \mathrm{m}\right)$. 


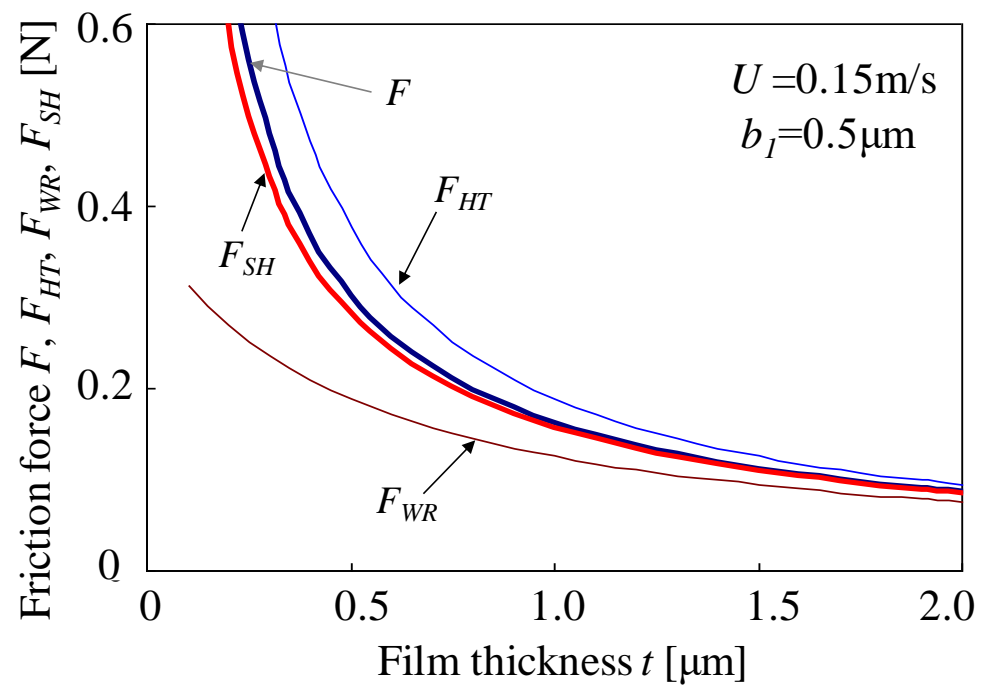

Fig. 16 Influence of slip on the friction force $F\left(b_{1}=0.5 \mu \mathrm{m}\right)$. The frictional force $F$ of this bearing appears between $F_{H T}$ and $F_{W R}$, and it shows almost the same value as the friction force $F_{S H}$ ignored the pressure flow. In addition, the remarkable influence of slip length on the friction force is not recognized since there is no significant difference between the $F_{H T}$ (entire surface is non slip) and $F_{S H}$.

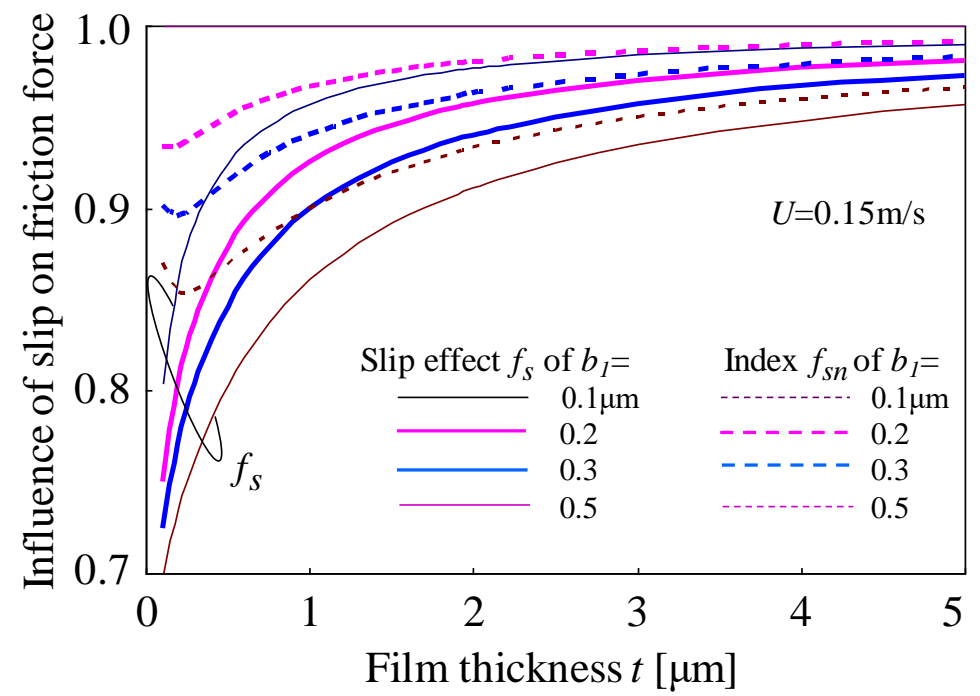

Fig. 17 Influence of slip on friction force $\left(f_{s}\right.$ : solid line $)$ and index normalized by $f_{s}$ of $b_{1}=0.1 \mu \mathrm{m}\left(f_{s n}\right.$ : broken line $)$. The influence value $f_{s}$ of the slip decreases as the lubrication film becomes thinner, and it performs to reduces the increase in friction force due to reduction of film thickness. However, the index $f_{s n}$ is within 0.85 to 1.0, and the difference in friction force at each slip length $b_{1}$ is not significant.

また, 軸受全面を非スリップとした場合の摩擦力 $F_{H T}$ と上記 $F_{S H}$ との間に著しい差がないことから, 前述の $(4)$ に示したように，摩擦力 $F$ に対するスリップ長さ $b_{1}$ の影響は顕著ではないことが分る. 図 17 には, 式 (8) にお いてスリップの影響を表わす $\left[\right.$ ]内の值の大きさ $f_{s}$ を実線で，また， $b_{1}=0.1 \mu \mathrm{m}$ での值で規格化した指標值 $f_{s n}$ を破 線で示してある. どのスリップ長さ $b_{1}$ においても，スリップの影響值 $f_{s}$ は薄膜化により低下しており，膜厚の減 少に伴なう摩擦力の上昇を抑える方向に作用しているが， $b_{1}=0.1 \mu \mathrm{m}$ との比 $f_{s n}$ は概ね $0.85 \sim 1.0$ 以内に留まってお り，上述のように摩擦力 $F$ に対するスリップ長さ $b_{1}$ の影響は顕著ではないことを示唆している.

ちなみに薄膜領域では，上述のように圧力流れによりスリップが抑制されるため，支持荷重に対するスリップ 長さの影響もまた少なくなる。これにより（ 7 ）に示したように，薄膜領域ではスリップ長さ $b_{1}$ の違いによる摩 擦係数の差は少なくなる. 


\section{5. 結 言}

すべり方向に撥水（スリップ）領域と親水（非スリップ）領域を交互に配置し，両領域でのせん断流量の不連 続性により圧力を発生させて荷重を支持する，部分撥水型フラットスラスト軸受の水潤滑下での基礎実験と，最 も単純な無限幅軸受近似理論による同軸受の基礎潤滑特性に対する一考察を行い，以下の結果を得た。

1) 本軸受の寸べり方向の圧力は，撥水領域で上昇し，親水領域で下降しており，従来のステップ軸受と類似な 圧力分布となる．また，両領域の境界での圧力 $p_{M}$ は，荷重にほぼ比例して増加する.

2 ）スリップ長さが大きいと考えられる撥水性の高い面では，スリップによりせん断流れの速度勾配が小さくな ることに加え, 同じ荷重を支持する際の膜厚が厚くなることもあり, 軸受の摩擦係数は低く現れる.

3 ）無限幅軸受近似理論により本軸受の潤滑特性を検討した結果，以下の基礎的事項を確認できた.

(a) スリップ長さが大きい面ほどせん断流れのスリップ速度 $u_{s s}$ が大きくなり, スリップ領域でのせん断流量 が増加するため, 特に小さなスリップ長さ領域で支持荷重は急増する. しかし, スリップ長さが大きな面 や膜厚が薄い状況下では, 高い圧力の発生により, せん断流れのスリップを抑制する向きの圧力流れの 速度成分 $u_{s p}$ が増大寸るため, 支持荷重の増加の程度は, スリップ長さの増大と共に, そして膜厚の減少 と共に徐々に緩慢になる.

（b）スリップ長さが大きく，スリップ領域での速度勾配が減少する軸受面ほど摩擦力は低くなる. しかし, 比較的大きなスリップが発生する部分スリップ軸受でも摩擦力 $F$ に対する圧力流れの影響は小さく, $F$ は圧力流れを無視した場合の摩擦力 $F_{S H}$ とほぼ同じ值を示す. また, 軸受全面を非スリップとした場合の 摩擦力 $F_{H T}$ と, 部分スリップ軸受においてせん断流れだけを考慮した場合の摩擦力 $F_{S H}$ との間には著しい 差は無く，摩擦力に対するスリップ長さの影響はほとんど認められない.

(c) 膜厚の減少に対する摩擦力の増加の程度は，支持荷重の増加の程度に比べて緩慢であるため, 摩擦係数 は膜厚の減少と共に低下寸る．特に薄膜領域で急激な低下を示寸が，この領域では前述のように圧力流 れによるスリップの抑制が強く現れ，支持荷重に対するスリップ長さの影響が小さくなることもあり， スリップ長さの違いによる摩擦係数の差は少なくなる.

以上のように，部分撥水（スリップ）フラットスラスト軸受の特性には，撥水（スリップ）領域でのスリップ 長さや軸受面間の膜厚が影響するが，いずれのスリップ長さや膜厚においても，スリップの効果は支持荷重を増 大させ，摩擦力の上昇を抑える方向，したがって，軸受特性を改善する方向に作用するため，本報のような低荷 重・低回転用のスラスト軸受としての可能性が期待できる.

\section{謝 辞}

最後に，平成 30 年度補助金（基盤研究 $C$ ，課題番号 $18 \mathrm{~K} 03913$ ），による研究の一部である. ここに付記して御 礼申し上げる.

\section{文献}

Choo, H. J., Glovnea, P. R., Forrest, A. K. and Spikes, A. H., A low friction bearing based on liquid slip at the wall, Transactions of the ASME Journal of Tribology, Vol.129 (2007a), pp.611-620.

Choo, H. J., Spikes, A. H., Ratoi, M., Glovnea, P. R. and Forrest, K. A., Friction reduction in low-load hydrodynamic lubrication with a hydrophobic surface, Tribology International, Vol.40 (2007b), pp.154-159.

Fortier, A. E. and Salant, R. F., Numerical analysis of a journal bearing with a heterogeneous slip/no-slip surface, Transactions of the ASME Journal of Tribology, Vol.127 (2005), pp.820-825.

Hamid, N. and Morteza, A., Slip flow over micron-sized spherical particles at intermediate Reynolds numbers, Journal of Mechanical Science and Technology, Vol.26, No.9 (2012), pp.2741-2749. 
Hirayama, T., Uno, T., Torii, T., Matsuoka, T., Inoue, K., Ebisawa, T., Tasaki, S., Hino, M. and Torikai, N., Water density near surface of DLC films having various surface energies measured by neutron reflectometry, Activity Report on Neutron Scattering Research: Experimental Reports, Vol.15 (2008), Report Number-637.

橋本巨，和田稲苗，清川雅充，ステップスラスト軸受の圧力分布に及ぼす流体慣性の影響（第 1 報，入口端の圧 力変動が無視できる場合の理論解析），日本機械学会論文集 C 編，Vol. 51, No. 461 (1985), pp. 81-87.

加納好昭，柴田貴章，西村隆文，薄井洋基，佐伯隆，溶融樹脂の管内流動における壁面スリップ（固体界面の影 響)，日本レオロジー学会誌，Vol.25, No.1 (1997), pp.37-41.

加納好昭, 柴田貴章, 薄井洋基, 八尾滋, 庄司達也, 固体界面における溶融樹脂のぬれとスリップに関する研究, 日本レオロジー学会誌, Vol. 24, No. 4 (1996), pp.177-181.

川原公介, 沢田博史, 横谷篤至, 流体潤滑にあるしゅう動表面のぬれ性による摩擦への影響, 砥粒加工学会誌, Vol.54, No.6 (2010), pp. 366-372.

Ma, G. J., Wu, C. W. and Zhou, P., Wall slip and hydrodynamics of two-dimensional journal bearing, Tribology International, Vol.40, No.7 (2007), pp.1056-1066.

Millikan, R. A., The general law of fall of a small spherical body through a gas, and its bearing upon the nature of molecular reflection from surfaces, Physical Review, Vol.22, No.1 (1923a), pp.1-23.

Millikan, R. A., Coefficient of slip in gases and the law of reflection of molecules from the surfaces of solids and liquids, Physical Review, Vol.21, No.3 (1923b), pp.217-238.

長山暁子，固液界面の境界条件とマイクロ伝熱機構，伝熱，Vol.50, No.211 (2011), pp.29-36.

長山暁子，鶴田隆治，分子動力学的視点からみた固液界面の濡れ機構，伝熱，Vol.46, No.194 (2007), pp.12-19.

中村隆，しゅう動面潤滑機構と材料技術，デンソーテクニカルレビュー，Vol. 7, No. 2 (2002), pp. 3-11.

Pentyala, S. R. and Santosh, A., Effect of slip/no-slip on finite slider bearing using non-Newtonian micropolar fluid, Jurnal Tribologi, Vol.19 (2018), pp.79-87.

Rao, T. V. V. L. N., Theoretical prediction of journal bearing stability characteristics based on the extent of the slip region on the bearing surface. Tribology Transactions, Vol.52 (2009), pp.750-758.

Rao, T. V. V. L. N., Rain, A. M. A., Nagarajan, T. and Hashim, F. M., Analysis of slider and journal bearing using partially textured slip surface, Tribology International, Vol.56 (2012), pp.121-128.

Salant, R. F., Numerical simulation of a mechanical seal with an engineered slip/no-slip face surface, 17th International Conference on Fluid Sealing, BHR Group Ltd. (2003), pp.15-28.

Snehal, S. and Gunamani, D., Effect of slip velocity on magnetic fluid lubrication of rough porous Rayleigh step bearing, Journal of Mechanical Engineering and Sciences, Vol.4 (2013), pp.532-547.

Takeuchi, A., Investigation of water-repellent thrust bearing, Tribology Online, Vol.5, No.3 (2010), pp.161-164.

竹内彰敏, 部分穴埋め型多孔質スラス卜軸受の水潤滑特性に関する実験的研究, 日本機械学会論文集 C 編, Vol.77, No.775 (2011), pp.1133-1142.

竹内彰敏, 部分撥水処理を施した平坦なスラスト軸受の超音波膜厚測定, 日本機械学会論文集 C 編, Vol.79, No.802 (2013), pp. 2164-2173.

竹内彰敏, 部分撥水スラスト軸受の発生圧力に及ぼす濡れ性調整領域の影響, 日本設計工学会 2016 年度秋季研究 発表講演会 (2016), pp.111-112.

竹内彰敏, 北邑有希雄, 部分撥水を施した平坦なスラスト軸受の水潤滑特性に関する実験的研究, 日本機械学会 論文集 C 編，Vol.77, No.779 (2011), pp.2905-2915.

Tauviqirrahman, M., Ajie, W. K., Yohana, E., Muchammad, M. and Jamari, J., A study of slip position on improving the hydrodynamic lubrication performance of single-textured bearing using a mass conserving numerical approach, International Journal of Engineering and Technology, Vol.8, No.2 (2016), pp.913-921.

Tauviqirrahman, M., Ismail R., Jamari, J. and Schipper, D. J., Combined effect of texturing and boundary slippage in lubricated sliding contacts. Tribology International, Vol.66 (2013), pp.274-81.

鳥居大地, 小原拓, 固体壁面間でせん断を受ける極薄液膜の分子動力学的研究（固液界面におけるエネルギー・ 運動量運搬に及ぼす固体結晶面の影響)，日本機械学会論文集 B 編，Vol.71, No.710 (2005), pp.2507-2514. 
Voronov, R., Papavassiliou, D. and Lee, L., Boundary slip and wetting properties of interfaces: Correlation of the contact angle with the slip length, The Journal of Chemical Physics, Vol.124 (2006), 204701, pp.1-10.

渡辺敬三，小方聡，超はっ水性回転円板のニュートン流体における摩擦抵抗の低減について，日本機械学会論文 集 B 編，Vol.63, No.612 (1997), pp.2752-2756.

渡辺敬三, Yanuar, 水沼 博, ニュートン流体の固体境界における滑りについて, 日本機械学会論文集 B 編, Vol.63, No.611 (1997), pp.2330-2334.

渡辺敬三，Yanuar，大木戸勝利，水沼 博，超はっ水性矩形管の抵抗減少効果に関する研究，日本機械学会論文集 B 編, Vol.62, No.601 (1996), pp.3330-3334.

Zhu, Y. and Granick, S., Rate-dependent slip of Newtonian liquid at smooth surfaces, Physical review letters, Vol.87, No.9 (2001), 096105, pp.1-4.

\section{References}

Choo, H. J., Glovnea, P. R., Forrest, A. K. and Spikes, A. H., A low friction bearing based on liquid slip at the wall, Transactions of the ASME Journal of Tribology, Vol.129 (2007a), pp.611-620.

Choo, H. J., Spikes, A. H., Ratoi, M., Glovnea, P. R. and Forrest, K. A., Friction reduction in low-load hydrodynamic lubrication with a hydrophobic surface, Tribology International, Vol.40 (2007b), pp.154-159.

Fortier, A. E. and Salant, R. F., Numerical analysis of a journal bearing with a heterogeneous slip/no-slip surface, Transactions of the ASME Journal of Tribology, Vol.127 (2005), pp.820-825.

Hamid, N. and Morteza, A., Slip flow over micron-sized spherical particles at intermediate Reynolds numbers, Journal of Mechanical Science and Technology, Vol.26, No.9 (2012), pp.2741-2749.

Hirayama, T., Uno, T., Torii, T., Matsuoka, T., Inoue, K., Ebisawa, T., Tasaki, S., Hino, M. and Torikai, N., Water density near surface of DLC films having various surface energies measured by neutron reflectometry, Activity Report on Neutron Scattering Research: Experimental Reports, Vol.15 (2008), Report Number-637.

Hashimoto, H., Wada, S. and Kiyokawa, N., Suteppu surasuto jikuuke no stsuryokubunpu ni oyobosu ryuutaikansei no eikyou (daiippou, irigutitan no atsuryokuhenndou ga musi dekiru baai no riron kaiseki), Transactions of the Japan Society of Mechanical Engineers, Series C, Vol.51, No.461 (1985), pp.81-87 (in Japanese).

Kanoh, Y., Shibata, T., Nishimura, T., Usui, H. and Saeki, T., Wall slip of molten polymers In various conduits -Influence of solid surface conditions-, Nihon reoroji gakkaishi, Vol.25, No.1 (1997), pp.37-41 (in Japanese).

Kanoh,Y., Shibata, S., Ysui, H., Yao, S. and Shoji, T., An influence of contact surface wetting on wall slip in a flow of molten polymer, Nihon reoroji gakkaishi, Vol.24, No.4 (1996), pp.177-181 (in Japanese).

Kawahara, K., Sawada, H. and Yokotani, A., Influence of wettability of sliding surface under hydrodynamic lubrication on friction, Journal of the japan society for abrasive technology, Vol.54, No.6 (2010), pp.366-372 (in Japanese).

Ma, G. J., Wu, C. W. and Zhou, P., Wall slip and hydrodynamics of two-dimensional journal bearing, Tribology International, Vol.40, No.7 (2007), pp.1056-1066.

Millikan, R. A., The general law of fall of a small spherical body through a gas, and its bearing upon the nature of molecular reflection from surfaces, Physical Review, Vol.22, No.1 (1923a), pp.1-23.

Millikan, R. A., Coefficient of slip in gases and the law of reflection of molecules from the surfaces of solids and liquids, Physical Review, Vol.21, No.3 (1923b), pp.217-238.

Nagayama, G., Boundary conditions and microscale heat transfer of solid-liquid interface, Journal of the Heat Transfer Society of Japan, Vol.50, No. 211 (2011), pp.29-36 (in Japanese).

Nagayama, G. and Tsuruta, T., Wetting behavior of the solid-liquid interface based on molecular dynamics studies, Journal of the Heat Transfer Society of Japan, Vol.46, No.194 (2007), pp.12-19 (in Japanese).

Nakamura, T., Lubrication mechanism of slide way and material technology, DENSO technical review, Vol. 7, No. 2 (2002), pp. 3-11 (in Japanese). 
Pentyala, S. R. and Santosh, A., Effect of slip/no-slip on finite slider bearing using non-Newtonian micropolar fluid, Jurnal Tribologi, Vol.19 (2018), pp.79-87.

Rao, T. V. V. L. N., Theoretical prediction of journal bearing stability characteristics based on the extent of the slip region on the bearing surface. Tribology Transactions, Vol.52 (2009), pp.750-758.

Rao, T. V. V. L. N., Rain, A. M. A., Nagarajan, T. and Hashim, F. M., Analysis of slider and journal bearing using partially textured slip surface, Tribology International, Vol.56 (2012), pp.121-128.

Salant, R. F., Numerical simulation of a mechanical seal with an engineered slip/no-slip face surface, 17th International Conference on Fluid Sealing, BHR Group Ltd. (2003), pp.15-28.

Snehal, S. and Gunamani, D., Effect of slip velocity on magnetic fluid lubrication of rough porous Rayleigh step bearing, Journal of Mechanical Engineering and Sciences, Vol.4 (2013), pp.532-547.

Takeuchi, A., Investigation of water-repellent thrust bearing, Tribology Online, Vol.5, No.3 (2010), pp.161-164.

Takeuchi, A., Experimental study on water lubrication characteristics of porous thrust bearing with partial filled parts, Transactions of the Japan Society of Mechanical Engineers, Series C, Vol.77, No.775 (2011), pp.1133-1142 (in Japanese).

Takeuchi, A., Ultrasonic measurement of film thickness in partial water repellent full-flat thrust bearing, Transactions of the Japan Society of Mechanical Engineers, Series C, Vol.79, No.802 (2013), pp.2164-2173 (in Japanese).

Takeuchi, A., Influence of wettability coordination area for pressure generation of partial water-repellent thrust bearing, Nihon sekkei kogakukai 2016 nendo shuuki kenkyuu happyo kouenkai (2016), pp.111-112 (in Japanese).

Takeuchi, A. and Kitamura, Y., Experimental study on water lubrication characteristics of full-flat thrust bearing with partial water-repellent surface, Transactions of the Japan Society of Mechanical Engineers, Series C, Vol.77, No.779 (2011), pp. 2905-2915 (in Japanese).

Tauviqirrahman, M., Ajie, W. K., Yohana, E., Muchammad, M. and Jamari, J., A study of slip position on improving the hydrodynamic lubrication performance of single-textured bearing using a mass conserving numerical approach, International Journal of Engineering and Technology, Vol.8, No.2 (2016), pp.913-921.

Tauviqirrahman, M., Ismail R., Jamari, J. and Schipper, J. D., Combined effect of texturing and boundary slippage in lubricated sliding contacts. Tribology International, Vol.66 (2013), pp.274-81.

Torii, D. and Ohara, T., Molecular dynamics study on ultra-thin liquid film sheared between solid surfaces (influence of the crystal plane to energy and momentum transfer at the solid-liquid interfaces), Transactions of the Japan Society of Mechanical Engineers, Series B, Vol.71, No.710 (2005), pp.2507-2514 (in Japanese).

Voronov, R., Papavassiliou, D. and Lee, L., Boundary slip and wetting properties of interfaces: Correlation of the contact angle with the slip length, The Journal of Chemical Physics, Vol.124 (2006), 204701, pp.1-10.

Watanabe, K. and Ogata, S., Drug reduction for a rotating disk with highly water repellent wall in Newtonian fluids, Transactions of the Japan Society of Mechanical Engineers, Series B, Vol.63, No.612 (1997), pp.2752-2756 (in Japanese).

Watanabe, K., Yanuar and Mizunuma, H., Slip of newtonian fluids at solid boundary, Transactions of the Japan Society of Mechanical Engineers, Series B, Vol.63, No.611 (1997), pp.2330-2334 (in Japanese).

Watanabe, K., Yanuar, Okido, K. and Mizunuma, H., Drag reduction in flow through square and rectangular ducts with highly water-repellent walls, Transactions of the Japan Society of Mechanical Engineers, Series B, Vol.62, No.601 (1996), pp.3330-3334 (in Japanese).

Zhu, Y. and Granick, S., Rate-dependent slip of Newtonian liquid at smooth surfaces, Physical review letters, Vol.87, No.9 (2001), 096105, pp.1-4. 